УДК 338.242 .2

DOI: https://doi.org/10.37320/2415-3583/21.11

Скібіцька Л.І.

кандидат економічних наук Національний авіаційний університет ORCID: https://orcid.org/0000-0001-5042-2701

\title{
БІЗНЕС-МОДЕЛІ ТА НОВІТНІ ІНФОРМАЦІЙНІ ТЕХНОЛОГІї
}

Концепція бізнес-моделі часто використовується в контексті електронного бізнесу. Однак те, щзо ми бачимо сьогодні, є лите скромним початком. Розвиток в IT, імовірно, докорінно змінить природу фірми, а разом із нею $i$ сутність інновачій. У статті проаналізовано вплив новітніх інформаційних технологій на різні бізнес-моделі в роздрібній торгівлі, фармацевтичному ринку, туристичних послугах, електронних ринках тощо. Такий комбінований ефект мобільних технологій, переносних пристроїв, хмарних обчислень і технологій Big Data покращить структуру майбутніх бізнес-моделей. Однак традиційні форми інновачій залишаться важливими, стануть ключовими відмінностями, які вимагатимуть постійних безперервних інновацій і надалі вимагатимуть традиційних форм інновацій.

Ключові слова: підприємництво, бізнес, бізнес-модель, розвиток, новітні інформаційні технологї, впровадження.

Постановка проблеми. Використання в процесі аналізу вартості бізнесу масивів даних та різноманітного математичного апарату, неодноразове звернення до тих самих даних ставлять питання необхідності застосування інформаційних технологій. У нинішніх умовах глобального розвитку новітніх технологій необхідно вивчити вплив останніх на розвиток бізнес-моделей у різних сферах діяльності. Також необхідно проаналізувати комбінований ефект мобільних технологій, переносних пристроїв, гаджетів, хмарних обчислень і технологій Великих даних на бізнес-моделі. Необхідно дослідити такі сценарії: агенти по роботі з клієнтами, які $\epsilon$ цифровими представниками клієнтів на ринку, використовують дані для пошуку та пошуку рішень; координатори ланцюжка створення вартості, які координують попит та пропозицію, збирають індивідуальні рішення та беруть участь в електронних інноваціях на основі даних про клієнтів; виробники, які все більше залучаються до ринкових продажів та інновацій на основі даних.

Аналіз останніх досліджень і публікацій. Якісне інформаційне забезпечення будь-якого процесу управління бізнесом можливе лише за умови використання повною мірою всіх досягнень науково-технічного прогресу. Насамперед це стосується застосування у практиці аналізу новітніх інформаційних технологій: засобів обчислювальної техніки, програмного забезпечення та телекомунікацій. На важливість досліджень у галузі інформаційного забезпечення аналізу бізнесу вказували у своїх роботах багато вчених та практиків: А.Г. Грязнова [1], М.А. Федотова [2], Н.Д. Стрекалова [3], Л.В. Фролова, Е.С. Кравченко [4], Н.Н. Личкіна [5] та ін. Тим не менше у науковій та професійній літературі досі відсутні роботи, присвячені моделюванню інформаційної бази аналізу бізнесу.

Мета статті полягає в аналізі впливу новітніх інформаційних технологій на сучасні бізнес-моделі.

Виклад основного матеріалу. Професор Хаїм Мендельсон розглядає еволюцію бізнес-моделей через величезний вплив досягнень у сфері інформаційних технологій. У довгостроковій перспективі він бачить, що інформаційні технології продовжують розвиватися за поточною траєкторією продуктивності. Він стверджує, що комбінований ефект мобільних технологій, переносних пристроїв, хмарних обчислень і технологій Big Data (Великі дані) поліпшить структуру майбутніх бізнес-моделей. Із цією метою він передбачає такі сценарії: агенти 3 інтимності клієнтів, які є цифровими представниками клієнтів на ринку, використовують дані для пошуку та пошуку рішень, які зроблять їх краще; координатори ланцюга створення цінностей узгоджують попит і пропозицію, збирають індивідуальні рішення та беруть участь в електронних інноваціях на основі даних клієнтів; виробники все частіше займаються продажем на ринку та інноваціями на основі даних. Водночас він уважає, що традиційні форми інновацій залишатимуться ключовими відмінностями і що базові бізнес-моделі вимагатимуть безперервних інновацій, які, ймовірно, набудуть традиційної форми, а проривні продукти, як і раніше, вимагатимуть традиційних форм інновацій.

1.Визначення і приклади бізнес-моделей.

Бізнес-моделі - це стилізовані моделі, які описують, як компанії створюють і надають цінність своїм клієнтам і як вони отримують за це винагороду. Конструкція бізнес-моделі охоплює продукт або послугу, клієнта і ринок, роль компанії в ланцюжку створення вартості та економічний двигун, який дає їм змогу досягати своїх цілей прибутковості та зростання. Бізнес-моделі часто використовуються стартапами як інструменти моделювання, щоб допомогти їм спроєктувати, прототипувати та побудувати нові підприємства. Вони також використовуються відомими компаніями для планування, розвитку та підтримки свого інноваційного процесу. У цій статті використовується конструкція бізнес-моделі для того, щоб передбачити, як архітектура компаній і процеси розроблення бізнес-моделей будуть розвиватися в майбутньому.

Бізнес-модель - це структурований план, який намагається навести порядок і дисципліну в хаотичному процесі побудови, розвитку та управління бізнесом. Деякі автори широко визначають концепцію бізнес-моделі, що, на нашу думку, знижує зручність іiі використання. На нашу думку, концепція бізнес-моделі 
зосереджується на тому, як бізнес створює вартість та отримує доходи і прибутки, що визначається трьома основними елементами: моделлю створення вартості, моделлю прибутку та логікою бізнесу.

Визначення моделі створення изінності. Першим кроком у побудові або аналізі бізнес-моделі є специфікація моделі створення вартості. Це передбачає спочатку визначення цільових клієнтів і пропозиції, які створять для них диференційовану цінність. Диференціація важлива: щоб залучити клієнтів і отримати прибуток, пропозиція має бути кращою за конкурентів у вимірі, який істотно впливає на клієнтів. Розміри диференціації відрізняються в різних компаніях. Наприклад, Walmart створює диференційовану вартість для чутливих до витрат споживачів, продаючи широкий асортимент товарів за низькими цінами. Apple створює диференційовану цінність для споживачів, які готові платити за добре розроблені, «круті» інноваційні продукти.

Наявність продукту чи послуги, яка справді вирішує значну проблему для чітко визначеного сегмента клієнтів, є хорошим початком, але цього недостатньо. Будь-який бізнес повинен мати ефективні стратегії виходу на ринок, які зосереджені на виведенні продукту чи послуги на ринок, залученні клієнтів, забезпеченні доходу та позиції ринку, а також розвитку ринку. Стратегія виходу на ринок визначає, як компанія залучатиме клієнтів і як вона в кінцевому підсумку забезпечить їм цінність, яку вона створює.

Нарешті, створення вартості відбувається вздовж наскрізного ланцюга створення вартості. Однак компанії повинні вибрати, в яких частинах ланцюга створення вартості вони братимуть участь. Наприклад, компанія, яка розробляє нову технологію, може вирішити ліцензувати свою технологію відомим гравцям, не залучаючись ні до виробництва, ні до розповсюдження. Або компанія може виробляти продукт власноруч і продавати його як компонент більш відомій компанії, яка вбудовує його у свій власний брендований продукт. Іншою альтернативою $є$ виробництво та продаж продукту під власною торговою маркою компанії. Коли ми переходимо від першого варіанту до третього, компанія охоплює все більшу частину ланцюга створення вартості кінцевого продукту.

Визначення моделі прибутку. Модель прибутку бізнесу починається з визначення потоків його доходів і пов'язаних із ними витрат. Оскільки дохід і ціна є ключовим виміром вартості, створеної для клієнтів, вона пов'язує модель створення вартості 3 моделлю прибутку компанії.

Моделі доходу. Найпоширенішими моделями доходу є трансакційні: клієнти платять фіксовану ціну за одиницю товару чи послуги. Дохід від трансакцій також може включати фіксовані комісії та знижки за кількість. Другий тип моделі доходу - це модель передплати, згідно з якою клієнти сплачують фіксовану плату за одиницю часу, а натомість отримують фіксовану кількість одиниць продукту або послуги (наприклад, один примірник газети щодня в будні) або необмежену кількість використання протягом періоду підписки (наприклад, щомісячне членство в тренажерному залі).

Іншою моделлю доходу, яка зазвичай використовується для інтелектуальної власності, є модель ліцензу- вання, за якою клієнти сплачують роялті або ліцензійну плату, що дає їм змогу використовувати, продавати або копіювати продукт протягом певного періоду часу (необмежений у часі, якщо ліцензія безстрокова). Наприклад, програмне забезпечення здебільшого продається з використанням безстрокової ліцензії, і власник патенту може ліцензувати свою технологію іншим компаніям за плату за ліцензію.

Компанії часто отримують кілька потоків доходу, коли різні клієнти платять за різними формулами чи моделями доходу, або гібридні потоки доходу, коли платежі певного клієнта поєднують різні моделі доходу. Наприклад, на ринку еВау продавці сплачують абонентську плату, якщо вони «орендують» Інтернетмагазин еВау, комісію за перелік і комісію за кожну транзакцію, яка здійснюється на платформі. Ці збори відрізняються залежно від природи або транзакції, категорії продукту та формату ціни. Таким чином, ми можемо записати періодичний дохід як суму доходу від підписки, доходу від лістингу та доходу від транзакцій, де кожен із них, своєю чергою, має різні драйвери.

Структура витрат. Структура витрат визначає види діяльності, які сприяють різним витратам бізнесу. Наприклад, у виробничій операції витрати на матеріали пропорційні обсягу вироблених одиниць, тоді як витрати на доставку можуть залежати як від відстані доставки, так і від обсягу. Змінні витрати можуть бути пропорційними обсягу або вони можуть демонструвати економію від масштабу, наприклад придбані матеріали зі знижкою на кількість. У деяких випадках вони демонструють економію від масштабу, наприклад коли операція наближається до межі своєї потужності або коли ключових ресурсів настільки мало, що їхні граничні витрати зростають. Кожен із цих сценаріїв призводить до різної структури витрат.

Логіка бізнесу. Логіка бізнесу пояснює, як бізнес буде досягати своїх цілей прибутку та зростання. Він містить аргумент, який показує, чому бізнес буде успішним, тобто як він залучатиме клієнтів, бути конкурентоспроможним і прибутковим, а також рости. Це часто набуває форми «віртузного циклу», який показує, як основні елементи бізнес-моделі підсилюють один одного.

Існує кілька повторюваних архетипів бізнес-моделей, кожен $з$ яких характеризується своєю логікою. Нижче окреслено логіку трьох архетипів: перший заснований на близькості клієнта, коли бізнес адаптує рішення відповідно до попиту клієнта на передньому плані; другий заснований на операційній досконалості, яка грунтується на чудових внутрішніх процесах; третій заснований на координації ланцюга створення вартості, який створює вартість шляхом координації елементів ланцюга створення вартості. Ми вибрали ці три архетипи бізнес-моделей, оскільки вважаємо, що кожен зіграє важливу роль у структуруванні компанії майбутнього.

Інтимність клієнта: пошиття рішень на передньому плані. Наш перший архетип бізнес-моделі використовує інформацію про клієнта, щоб адаптувати рішення, які задовольняють унікальні або високоцільові потреби клієнтів. Цю логіку часто називають інтимністю клієнта.

Логіка близькості клієнта заснована на безперервних стосунках із клієнтами, що означає, що бізнес 
повинен ініціювати 3 ними явні або неявні діалоги, отримувати інформацію про їхню поведінку та переваги і використовувати цю інформацію, щоб налаштувати продукти або послуги відповідно до цих уподобань. Зближення 3 клієнтами практикується буквально тисячі років, але розвиток IT зробить його одним із центральних будівельних блоків компанії майбутнього.

Як приклад традиційної близькості до клієнтів розглянемо Ritz-Carlton, оператора п'ятизіркових розкішних готелів і курортів у всьому світі. Ritz-Carlton перша й єдина готельна компанія, яка двічі отримала престижну національну премію Malcolm Baldrige National Quality Award i є володарем багатьох нагород за високу якість обслуговування клієнтів. Кредо Ritz-Carlton звучить так: «Готель Ritz-Carlton - це місце, де справжня турбота та комфорт наших гостей $є$ нашою найвищою місією. Досвід Ritz-Carlton оживляє почуття, сприяє гарному самопочуттю і виконує навіть невисловлені бажання та потреби наших гостей».

Розробки в галузі IT зроблять близькість клієнта одним із центральних будівельних блоків компанії майбутнього. Щоб досягти своєї місії, компанія зосереджується на лояльності клієнтів за допомогою налаштувань, які покладаються на великий збір даних i користуються як ставленням співробітників, так і можливостями IT. Інформація збирається та записується під час кожної взаємодії з клієнтом та запиту на обслуговування. Інформація систематично заноситься в базу даних, яка доступна всім готелям Ritz-Carlton по всьому світу. Використовуючи базу даних, персонал готелю намагається щодня передбачати потреби кожного гостя та ініціювати кроки, які забезпечують індивідуальне високоякісне обслуговування. Гості надають Ritz-Carlton дедалі точнішу інформацію про свої вподобання та потреби, що дає змогу компанії надавати їм чудовий досвід. Завдяки цьому досвіду гості лояльні до Ritz-Carlton i, як правило, бронюють готель RitzCarlton, коли це можливо. Це, своєю чергою, дає RitzCarlton інформацію, яка дає змогу іiї персоналу обслуговувати гостей краще, ніж конкуренти, створюючи гідний цикл: інформація забезпечує чудовий досвід, що призводить до лояльності клієнтів, що створює ще кращу інформацію.

Операчійна досконалість: чудові внутрішні проиеси. Інша логіка керує ідеальними бізнес-моделями, які прагнуть мінімізувати вартість продуктів або послуг, які вони пропонують клієнтам, створюючи чудові внутрішні процеси. Маючи нижчу базу витрат, вони можуть мати цінову перевагу перед конкурентами. Окрім того, відмінні в операційному плані підприємства можуть установлювати конкурентоспроможні ціни на свою продукцію або послуги, одночасно зменшуючи нематеріальні витрати, які несуть їхні клієнти під час доставки продукції та послуг. Таким чином, операційна досконалість полягає не тільки у ціні. Розглянемо, наприклад, FedEx - всесвітньо відому американську транснаціональну логістичну компанію, яка намагається диференціювати свою пропозицію за своєчасністю та надійністю.

Walmart також $є$ прикладом оперативної досконалості в роздрібній торгівлі. Його слоган змінився від «Завжди низькі ціни» у шістдесятих до «Економте гроші. Live Better» останніми роками, але його модель і логіка створення цінності залишилися практично незмінними. Клієнти постійно називають низькі ціни основною причиною покупок у Walmart. Він продає велику різноманітність якісних товарів за нижчими цінами та більш високою доступністю, ніж більшість конкурентів, на основі своїх внутрішніх процесів.

Координація ланцююга створення вартості. Координатор ланцюга створення цінності може організовувати основні заходи по всьому ланцюжку створення вартості або бути зосередженим на вузькому зрізі ланцюга. У сфері електронної комерції координатори ланцюга створення вартості часто є платформними компаніями, які полегшують транзакції або взаємодію між користувачами своїх платформ. Вони передають безпосереднє створення вартості іншим учасникам ланцюга створення вартості, тоді як платформа сама координує діяльність, оптимізує бізнес-процеси та зменшує витрати на пошук і транзакції.

еВау - це класична онлайн-платформа, яка дає змогу покупцям і продавцям знаходити та торгувати один 3 одним. Тоді як користувачі платформи самі несуть тягар прямого створення вартості (еВау не зберігає і не продає товарні запаси, це роблять лише продавці), компанія зосереджена на тому, щоб зіставити покупців і продавців та полегшити транзакції між ними. Координатори ланцюга створення вартості, такі як еВау, постійно вдосконалюють свої платформи, щоб підвищити ефективність ланцюга створення вартості. Вони часто беруть участь у залученні нових клієнтів і запроваджують нові види діяльності, щоб створити додаткові джерела цінності для своїх клієнтів.

Ринок еВау.com - це бізнес-платформа, яка зосереджена на використанні інформаційних технологій для підтримки та полегшення торгових спільнот. Усі інші види діяльності здійснюються іншими особами: мерчандайзинг та інвентаризація продукції продавцями; доставка через логістичні партнери еВау (наприклад, національні поштові служби); фінансування, страхування та перевірки транспортних засобів на автомобільному ринку еВау надаються партнерами тощо. У результаті еВау може зосередитися на розвитку своєї технологічної платформи та на створенні активної торгової спільноти та розвитку вертикальних ринків, таких як еBay Motors, його колекційні предмети marketplace та його ринок квитків StubHub.

У сфері електронної комерції координатори ланцюга створення вартості часто $є$ платформними компаніями, які полегшують транзакції або взаємодію між своїми користувачами. Вони передають безпосереднє створення вартості іншим учасникам ланцюга створення вартості

\section{2. Розвиток бізнес-моделі.}

Інновації, які орієнтовані на клієнта. Як обговорювалося вище, бізнес-моделі відіграють ключову роль в інноваційному процесі. Існує багато підходів до інновацій, зосереджених на інноваційному підході, орієнтованому на клієнтів. Інновації, орієнтовані на клієнта, використовують конструкцію бізнес-моделі в ітераційному процесі, який зосереджується на цільовому клієнті (це іноді називають «розвитком клієнта»). Потім процес пов’язує клієнтів один з одним. Цей процес ініціюють із виявлення потреб клієнта, які недостатньо задоволені існуючими рішеннями на ринку. Потім процес 
продовжується 3 емпатією, глибоким етнографічним зануренням у життєвий та/або робочий досвід цільового клієнта. Емпатія включає три види діяльності:

- спостерігати - переглядати користувачів та їхню поведінку в контексті їхнього життя;

- залучати - взаємодіяти з користувачами та опитувати їх як запланованим, так і коротким «перехопленням» зустрічей;

- відчувати - відчуйте те, що відчуває ваш користувач.

Після етапу емпатії слідує етап визначення, який розпаковує та синтезує наші висновки щодо емпатії у переконливі потреби та ідеї, які дають нам змогу сформулювати актуальну постановку проблеми. За цим слідує етап ідей, який генерує численні потенційні ідеї вирішення. Метою етапу формування ідеї $\epsilon$ дослідження широкого і глибокого простору вирішення. Ідеї потім сортуються за допомогою конструкції бізнес-моделі, розглянутої вище: кожна ідея аналізується з погляду цінності, яку вона потенційно може створити для клієнтів, того, що потрібно для досягнення цієї цінності, а також результату прибутковості та потенціалу зростання. Це означає, що аналіз починається і зосереджується на потенціалі створення вартості, але потім фільтрується з використанням внутрішньої точки зору (зосередження уваги на здійсненності, вартості та прибутковості).

Початкова бізнес-модель, що виникає в результаті цього процесу, є неповною; це фактично прототип бізнес-моделі із заданою логікою. Щоб довести чи спростувати цю логіку, нам потрібно перевірити її центральні припущення. Таким чином, ми визначаємо ключові передумови та приступаємо до їх перевірки. Результати кожного тесту використовуються для перегляду бізнес-моделі, зміни іiі логіки, визначення нових центральних приміщень, перевірки їх по черзі та продовження ітерації. Цей ітеративний процес у кінцевому підсумку призводить або до бізнес-моделі, яка вважається життєздатною, або до відмови від специфічних інновацій на тій підставі, що, судячи 3 проведених сьогодні тестів, це навряд чи призведе до життєздатної бізнес-моделі. Останній результат часто проявляється у вигляді вичерпання фінансування.

На передньому плані процес фокусується на потребах клієнтів і створенні цінності. Зрештою, основна увага зосереджена на тому, щоб створити рішення, яке ефективно задовольняє потреби клієнта, враховує його витрати та намагається отримати прибуток. В обох випадках процес розроблення бізнес-моделі вимагає широкого людського судження, поєднуючи досвід i творчість. Як наслідок, на розроблення перевіреної, життєздатної бізнес-моделі потрібні місяці, квартали чи роки.

IT-тендениії та розвиток бізнес-моделі. Концепція бізнес-моделі часто використовується в контексті електронного бізнесу. Справді, використання терміна «бізнес-модель» з'явилося у середині дев'яностих років і йшло паралельно з розвитком Інтернету, переважна більшість його визначень у літературі пов'язана iз застосуванням IT.

Змінивши фокус інновацій з атомів на біти і з апаратного забезпечення на програмне забезпечення, IT різко прискорили процес розроблення бізнес-моделі. Розроблення прототипів i тестування, які раніше коштували сотні тисяч доларів, а виконання займало місяці, тепер можна ефективно завершити за тиждень за незначну суму. Програмне забезпечення $є$ більш пластичним, аніж апаратне забезпечення, що дає змогу адаптуватися до потреб клієнтів швидше, ніж будьколи раніше. Окрім того, розвиток хмарних обчислень зробив IT-інфраструктуру надзвичайно еластичною, що дає змогу швидко та ефективно тестувати і впроваджувати нові бізнес-моделі, засновані на програмному забезпеченні.

Однак те, що ми бачимо сьогодні, є лише скромним початком. Розвиток в IT, імовірно, докорінно змінить природу фірми, а разом із нею і сутність інновацій. Нижче розглянуто три із цих подій: конвергенція віртуальної та фізичної ідентичності, зближення моделей і реальності та зближення атомів і бітів. Усі три події дуже взаємопов'язані.

Конвергенція віртуальної та фізичної ідентичності. IT можна використовувати для створення віртуального відображення діяльності фізичного світу. Наприклад, рахунок кредитної картки споживача $€$ частковим цифровим відображенням його фінансового життя. Він включає (серед іншого) інформацію профілю, таку як ім'я споживача, адреса, кредитні дані і транзакційні дані. По суті, реальний споживач перебуває в тіні віртуальної особистості, яка відстежує деякі його фінансові дії. Історично інформація, закладена у цю віртуальну ідентичність, була досить неповною, оскільки більшість платежів здійснювалися готівкою, операції 3 кредитними картками здійснювалися із затримкою на кілька тижнів, і їх було важко пов'язати один $з$ одним. Сьогодні все більший відсоток платежів здійснюється в електронному вигляді, вони реєструються та доступні в режимі реального часу, і обробляти ix швидше, простіше й дешевше, щоб отримати більш повне уявлення про фінанси споживача. У результаті віртуальна особистість споживача забезпечує більш точне уявлення про його реальне фінансове життя. Віртуальні ідентифікатори зближуються 3 реальними в результаті збільшення використання мобільних пристроїв і використання хмарних обчислень.

Загалом віртуальні ідентифікатори зближуються 3 реальними в результаті збільшення використання мобільних пристроїв, а також використання хмарних обчислень. Мобільні пристрої супроводжують людей скрізь і торкаються багатьох різних аспектів повсякденної діяльності. Вони створюють багатий цифровий слід, який дає змогу відтворювати все більшу кількість споживчих дій - від фізичних переміщень до транзакцій і комунікацій. Хмарні обчислення, своєю чергою, дають змогу записувати дані в режимі реального часу, а також їх отримувати та обробляти за запитом. Це стосується не лише споживачів, а й пристроїв і машин, якими користуються підприємства. Чіпи радіочастотної ідентифікації дають змогу відстежувати продукт по всьому ланцюжку поставок, і все більше підключених датчиків збирають машинні дані в режимі реального часу. Отримані цифрові сліди створюють повне цифрове уявлення про фізичну активність пристроїв і машин, які становлять «промисловий Інтернет». Таким чином, віртуальні ідентичності зближуються до фізичних ідентичностей до такої міри, коли перші можуть служити ефективними сурогатами для останніх. 
Інтеграиія та конвергениія моделей $і$ реальності. Схожа тенденція стосується здатності створювати інтегровані високоточні моделі поведінки на основі кількох синхронізованих джерел даних. Наприклад, дані про поведінку клієнта можна об'єднати 3 даними соціальних мереж, щоб на основі власних минулих транзакцій і поведінки клієнта, а також його друзів зробити висновок, яка конфігурація продукту, ймовірно, буде найбільш привабливою для нього. Моделі «кількісного самопочуття» у сфері фітнесу та охорони здоров'я об'єднують дані з датчиків, що носяться, електронних медичних карт та інших джерел, щоб покращити самопочуття та продуктивність. Такі компанії, як Netflix, використовують оцінки клієнтів і звички перегляду в минулому разом 3 інформацією інших клієнтів і тенденціями на всьому ринку, щоб рекомендувати фільми та серіали, які можуть зацікавити клієнта.

Збіжність атомів $i$ бітів. Люди проводять усе більший відсоток свого часу у віртуальному світі, де за допомогою програмного забезпечення можна створювати індивідуальні інформаційні продукти та послуги. Програмне забезпечення може зробити «розрядні» продукти повністю відповідними вимогам клієнтів. Що стосується «атомів», то виробництво все більше керується програмним забезпеченням, яке дає змогу фізичним продуктам також краще реагувати на запити клієнтів. Роботів можна запрограмувати для підтримки гнучких і все ще недорогих виробничих процесів. Масове налаштування дає змогу компаніям поєднувати переваги масштабу з перевагами налаштувань для створення продуктів, які реагують на клієнтів. А низка нових технологій дає змогу створити унікальний, але доступний продукт для кожного клієнта - від футболок і взуття, виготовлених на замовлення, до унікальних промислових компонентів. Як наслідок, внутрішні процеси стають усе більш чутливими до запитів інтерфейсу.

Адитивне виробництво (також відоме як 3D-друк) це нова технологія, яка посилює цю тенденцію. Проєктування продукту за своєю суттю є інформаційною («бітовою») діяльністю, але перетворення дизайну в доступний фізичний продукт («атоми») вимагає дорогого інструменту та обладнання, що, своєю чергою, призводить до структури витрат, яка характеризує масове виробництво, засноване на економії масштабу. За допомогою 3D-друку цифровий дизайн можна перетворити на фізичний продукт по одній одиниці за один раз, збільшуючи змінну вартості одиниці. Сьогодні 3D-друк використовується переважно для створення прототипів продуктів, прискорюючи процес розроблення продукту, що призводить до масового виробництва продукції. Однак 3D-друк усе частіше використовується для створення індивідуальних подарунків, одягу та промислових компонентів, не кажучи вже про татуювання та продукти харчування. Сьогодні дорогі 3D-принтери переважно використовуються для створення пластикових виробів за лічені години. У майбутньому асортимент матеріалів, які виграють від 3D-друку, розшириться, а вартість і час на одиницю зменшаться. У результаті недороге виробництво повністю персоналізованих продуктів, скоріше за все, стане нормою, а не винятком. Це не означає, що масове виробництво зникне - скоріше за все, воно буде доповнено різноманітними доступними параметрами налаштування.

3. Бізнес-моделі в компаніях майбутнього.

Попереднє обговорення свідчить про те, що IT не лише прискорить процес розроблення бізнес-моделі, але й призведе 3 часом до суттєвих якісних змін. Ринок, що складається 3 агентів по роботі з клієнтами, постачальників/виробників i координаторів ланцюга створення вартості, зможе надати кращі рішення, ніж сучасні фірми. Агенти по роботі з клієнтами будуть спеціалізуватися на визначенні поточних і майбутніх уподобань клієнтів, а також на допомозі клієнтам у виборі альтернативних рішень. Виробники та постачальники спеціалізуватимуться на розробленні та продажу фізичних чи цифрових продуктів. Координатори ланцюга створення цінності будуть узгоджувати попит і пропозицію, конфігуруючи рішення, які використовують існуючі фізичні або цифрові продукти (або компоненти), а також будуть посередником у створенні нових продуктів на основі інформації, яку вони отримують, про переваги клієнтів і можливості постачальників. Такі структури вже існують сьогодні. Кілька ринків узгоджують попит і пропозицію на продукти (eВay), товари для бізнесу (Ariba), простір (Airbnb) та варіанти транспортування (Uber), і це лише кілька прикладів. Деякі з них пропонують послуги та індивідуальні рішення. Здебільшого, однак, клієнтам доводиться чітко вказувати свої вподобання в грубій формі, а потім їм доводиться витрачати час і зусилля і вирішувати, щоб зробити остаточний вибір. І розроблення нових продуктів знаходиться в компетенції виробників.

Щоб конкретно пояснити трансформацію, яка очікується, розглянемо, наприклад, ринок подорожей. Сьогодні споживачі можуть висловлювати свої вподобання щодо ціни та розкладу рейсів авіакомпанійконкурентів у пошуковій системі подорожей, яка потім переглядає дані постачальників і налаштовує для них рішення для подорожей. Майбутні бізнес-моделі в туристичній індустрії базуватимуться на трьох окремих функціях:

Агент 3 інтимності клієнтів відстежує вподобання споживача щодо подорожей і представляє його в процесі вибору. Концептуально агент може підтримувати інші види споживчої діяльності, окрім подорожей, але вважаємо, що експертиза у цій сфері залишатиметься важливою, і в результаті ми, ймовірно, матимемо агентів для певної сфери, принаймні на початку. Дивлячись на розклад споживача, плани на майбутнє та минулий досвід, агент постійно шукатиме проактивні рішення щодо подорожей, які можна запропонувати їм. У деяких випадках агент не зможе передбачити потреби споживача в подорожі; у цьому разі споживач ініціює пошук рішення, яким керуватиме агент від його імені. Легко уявити концептуально, як споживач міг би делегувати свій вибір подорожей агенту, який має вичерпні дані про весь досвід подорожей клієнта, розклад, альтернативну вартість часу, величезну інформацію про таких споживачів, здатність аналізувати альтернативи та вибрати найкраще рішення тощо. Ключові виміри конкуренції між клієнтськими агентами можуть базуватися на їхніх аналітичних здібностях та на їхній здатності постійно знаходити найкращі рішення для певного сегмента клієнтів. Модель доходу агента по 
роботі з клієнтами, ймовірно, буде заснована на підписці, а компонент залежатиме від продуктивності.

Постачальники туристичних послуг, які пропонують попередньо налаштовані компоненти для подорожей (подібні до сьогоднішніх розкладів рейсів і авіаквитків, а також доступних номерів у готелі та їх цін), а також вільну потужність, яка доступна для майбутньої конфігурації.

Координатор ланцюга створення цінності, який виступає посередником між агентами з інтимності клієнтів по відношенню до постачальників туристичних послуг. Координатор ланцюга створення цінності відіграє роль підприємця.

Координатор ланцюга створення вартості налаштовуватиме індивідуальні рішення, коли агент споживача запропонує це зробити. Він шукатиме різні сегменти польотів, готельні номери, транспорт до аеропорту тощо серед доступних попередньо налаштованих туристичних компонентів і запропонує їх агенту клієнта як повністю налаштовані рішення. Розподіл праці між агентом із забезпечення інтимності клієнта та координатором ланцюга створення цінності залежатиме від рівня довіри, який вони виробили з часом, а також від ступеня захисту даних клієнта.

Як підприємець координатор ланцюга створення вартості запропонує нові продукти, які постачальник, можливо, захоче запропонувати (окрім доступних попередньо налаштованих компонентів для подорожей), зіставляючи інформацію, зібрану від агентів 3 інтимності клієнта (тобто вподобання та потреби їхніх клієнтів) та постачальників (тобто наявні потужності для різних компонентів подорожі). Новий продукт може бути спеціальним або «масовим».

Аналогічно у випадку з промисловими продуктами агенти 3 інтимності клієнтів представляють уподобання потенційних покупців, постачальники пропонують продукти та можливості, які разом створюють потенційні рішення, а координатори ланцюга створення цінності можуть знайти відповідність покупцям i продавцям, створювати рішення 3 доданою вартістю, додаючи рішення постачальників, запропонувати створення унікальних продуктів на замовлення або замовити розроблення нових продуктів, які можуть бути продані кільком покупцям.

Просту аналогію із цією формою автоматизованих інновацій надає використання комбінаторної хімії у фармацевтичній промисловості. Розроблення ліків це тривалий процес, який може тривати від десяти до двадцяти років із застосуванням традиційних методів. За допомогою комбінаторної хімії молекулярні конструкції автоматично синтезуються та перевіряються на біологічну активність. Ця техніка використовує кілька молекулярних будівельних блоків і використовує автоматизований процес для створення численних комбінацій шляхом змішування та поєднання цих буді- вельних блоків. Таким чином, замість того щоб займатися ручним, тривалим процесом скринінгу, машини створюють тисячі ліків щодня шляхом змішування хімічних речовин у заздалегідь визначених умовах тестування. Цей процес «високопродуктивного скринінгу» дає змогу паралельно тестувати відведення ліків, що значно прискорює процес розроблення ліків. Після визначення результатів скринінгових аналізів вони зберігаються у цифрових бібліотеках, замінюючи лабораторні тести in vitro (тобто тести «пробірки») тестами in silico (тобто комп'ютерними) з використанням комп'ютерних програм для швидкого перегляду цифрових комбінаторних бібліотек.

Звертаючись до бізнес-моделі постачальників/ виробників, вони включатимуть три види діяльності: 1) пропонування попередньо налаштованих компонентів і продуктів, а також варіантів налаштування на ринку, як правило, через координаторів ланцюга створення вартості; 2) залучення до електронних інновацій, орієнтованих на клієнтів, разом із координаторами ланцюга створення вартості, як обговорювалося вище; 3) залучення до традиційних інновацій, орієнтованих на клієнтів, для нових продуктів і ідей послуг, які не були виведені в електронному вигляді.

Остання форма інновацій і надалі залишатиметься важливою. Хоча електронні інновації, орієнтовані на клієнтів, можуть добре працювати для продуктів, які є природним розширенням існуючих продуктів, завжди будуть проривні продукти, про успіх яких неможливо визначити 3 наявних даних. Насправді, здатність залучатися до більш традиційних інновацій, орієнтованих на клієнтів, може бути сильною відмінністю для найуспішніших розробників продуктів.

Висновки. У статті розглянуто вплив розвитку IT на майбутні бізнес-моделі та процеси їх розроблення. Стверджується, що комбінований ефект мобільних технологій, переносних пристроїв, гаджетів, хмарних обчислень і технологій Великих даних загострить структуру майбутніх бізнес-моделей. Три з них відіграватимуть особливо важливу роль у використанні IT: 1) агенти 3 контакту 3 клієнтами будуть цифровими представниками клієнтів на ринку, використовуючи дані для пошуку рішень, які зроблять їх краще; 2) координатори ланцюга створення цінності відповідатимуть попиту та пропозиції, збиратимуть індивідуальні рішення та залучатимуться до електронних інновацій, що керуються даними клієнтів; 3) виробники все частіше будуть займатися продажем на ринку та інноваціями на основі даних. Однак традиційні форми інновацій залишаться важливими і стануть ключовими відмінностями. По-перше, основні бізнес-моделі вимагатимуть безперервних інновацій, які, ймовірно, набудуть традиційної форми. По-друге, проривні продукти, ймовірно, і надалі вимагатимуть традиційних форм інновацій.

Список використаних джерел:

1. Оценка бизнеса / под ред. А.Г. Грязновой, М.А. Федотовой. Москва : Финансы и статистика, 2009. С. 11-39.

2. Федотова М.А., Уткин Э.А. Оценка недвижимости и бизнеса : учебник. Москва : Тандем, 2000. 352 с.

3. Стрекалова Н.Д. Концепция бизнес-модели: методология системного анализа. Известия Российского государственного педагогического университета имени А.И. Гериена. 2009. № 92. С. 96.

4. Фролова Л.В., Кравченко Е.С. Формирование бизнес-модели предприятия. Киев : Центр учебной литературы, 2012.384 с.

5. Лычкина Н.Н. Имитационное моделирование экономических процес сов : учебное пособие. Москва : ИНФРА-М, 2012. 254 c. 


\section{References:}

1. Hryaznova A.H., Fedotova M.A. (2009) Otsenka biznesu [Business Valuation]. Moscow: Finansy i statistika. (in Russian)

2. Fedotova M.A., Utkin E.A. (2000) Otsenka nerukhomosti i biznesu [Real Estate and Business Valuation]. Moscow: EKMOS. (in Russian)

3. Strekalova N.D. (2009) Kontseptsyya biznes-modely: metodolohyya systemnoho analizu [Business Model Concept: Systems Analysis Methodology]. No. 92. P. 96. (in Russian)

4. Frolova L.V., Kravchenko E.S. (2012). Formuvannya biznes-modely predpryyatyya [Formation of the business model of the enterprise]. Kyiv: Tsentr uchebnoy lyteratury. (in Ukrainian)

5. Lychkyna N.N. (2012). Ymytatsyonnoe modelyrovanye ékonomycheskykh protsessov: ucheb. posobye [Simulation of economic processes: a tutorial]. Moscow: INFRA-M (in Russian)

Skibitska Liana

National Aviation University

\section{BUSINESS MODELS AND THE LATEST INFORMATION TECHNOLOGIES}

The article is devoted to the study of the impact of the latest information technologies on existing business models. The conceptual apparatus of business models is considered. The evolution of business models is considered, considering the huge impact of advances in information technology. It is revealed that information technologies continue to develop along the current trajectory of productivity. It is substantiated that the combined effect of mobile technologies, portable devices and sensors, cloud computing and Big Data technologies will improve the structure of future business models. The concept of business model is often used in the context of e-business. However, what we see today is only a modest beginning. Developments in IT are likely to radically change the nature of the firm, and with it the essence of innovation. The article analyses the impact of the latest information technologies on various business models in retail, pharmaceutical market, travel services, electronic markets and more. The following scenarios have been explored: Client intimacy agents, who are the digital representatives of clients in the market, use data to find and find solutions that will make them better. Value chain coordinators coordinate supply and demand, collect individual solutions and participate in e-innovation based on customer data. Manufacturers are increasingly engaged in market sales and databased innovation. The definition of the value creation model and the profit model is given. The structure of expenses is revealed. Developments in the field of IT in various business models are considered. Innovations focused on customer and IT trends and business model development are studied. The article analyses the impact of the latest information technologies on various business models in retail, pharmaceutical market, travel services, electronic markets and more. This combined effect of mobile technology, portable devices, cloud computing and Big Data technologies will improve the structure of future business models. However, traditional forms of innovation will remain important, will become key differences that will require continuous continuous innovation and will continue to require traditional forms of innovation.

Key words: entrepreneurship, business, business model, development, latest information technologies, implementation.

JEL classification: O32, O33, M15, P47, D20 